\title{
Antibacterial Activity Assay Of Ethanolic Extract Of Bulbs Sticky Taro (Colocasia esculenta) Use TLC-Bioautografi
}

\author{
Achmad Rosyadi Yusuf Hibai, Herwin, Rachmat Kosman
}

Fakultas Farmasi Universitas Muslim Indonesia

Email : herwinfarmasi@gmail.com.

\begin{abstract}
A research on antibacterial activity assay of sticky ethanolic extract from taro tuber (Colocasia esculenta) has been conducted in order to determine the antibacterial activity of ethanolic extract of the stem Colocasia esculenta against several assay bacteria use TLC-Bioautografi. Results of antibacterial activity screening showed that the ethanol extract of te Colocasia esculenta at a concentration of $1 \mathrm{mg} / \mathrm{ml}$ exhibited inhibitory activity against bacteria of Bacillus subtilis, Escherichia coli, Pseudomonas aerugginosa, Salmonella typhi, Shigella dysentriae, Staphylococcus aureus, Staphylococcus epidermidis, Streptococcus mutans, and Vibrio cholera. Test result showed by TLC-Bioautography using the eluent $n$-hexane : ethyl acetate (4:1) obtained Rf 0.38 value providing activity to Escherichia coli, Pseudomonas aerugginosa, Salmonella typhi, Shigella dysentriae, Staphylococcus aureus, Streptococcus mutans, and Vibrio cholera. The results of identification of active chemical component showed that the ethanolic extract of the stem of Colocasia esculenta on Rf 0.38 value was te alkaloid using dragendorf as the reagent.
\end{abstract}

Keywords : Colocasia esculenta, TLC-Bioautogaraphy, Antibacterial.

\section{PENDAHULUAN}

Indonesia merupakan negara yang kaya akan sumber daya alam. Hal ini ditunjang dari iklim tropis yang ada di Indonesia.Dengan sumber daya alam tersebut memiliki banyak potensi yang dapat dimanfaatkan, seperti jenis tumbuhan/tanaman yang dapat dimanfaatkan sebagai obat tradisional.

Salah satu tumbuhan yang dapat dimanfaatkan sebagai obat tradisional adalah talas ketan
(Colocasiaesculenta) dengan berbagai macam kandungan kimia mengandung 6-C-glikosilflavonoid dan Oglikosilflavonoid, diantaranya schaftoside, isoschaftoside, orientin, isovitexin, isoorientin, vitexin dan luteolin 7- $O$-sophoroside (Leong, 2009).

Dalam penelitian lain disebutkan pula kandungan daun talas diantaranya saponin, terpen, tanin, flavonoid, flobatanin, antraquinon, 
Antibacterial Activity Assay Of Ethanolic Extract Of Bulbs Sticky Taro (Colocasia esculenta) Use TLC-Bioautografi

glikosida jantung, dan alkaloid (Biren et all., 2007; dan Eddy, 2009).

Umbi talas ketan (Colocasia esculenta) secara empiris digunakan oleh masyarakat sebagai obat scrofula, radang kulit bernanah, psoriasis, tumor di rongga perut, berak darah, keseleo, ketombe, bisul, dan luka bakar. Sementara tangkai dan daunnya digunakan untuk pengobatan urticaria, diare, dan pembalut luka. Hal tersebut dikarenakan tanaman talas mengandung senyawa-senyawa polifenol dan saponin (Setiawan, 1999).

Meski diyakini talas ketan (Colocasia esculenta) memiliki banyak khasiat dalam pengobatan, namun penggunaannya sebagai antimikroba secara ilmiah masih sangat kurang, sehingga dalam rangka pemanfaatannya sebagai bahan obat alam seperti talas ketan (Colocasia esculenta), maka penelitian ini ditujukan untuk menguji aktivitas antibakteri dari ekstrak umbi talas ketan (Colocasia esculenta) terhadap beberapa bakteri uji agar penggunaannya dalam masyarakat lebih dapat dipertanggungjawabkan.

\section{METODOLOGI PENELITIAN}

\section{Waktu dan Tempat Penelitian}

Waktu penelitian dilaksanakan pada bulan Februari 2013 sampai selesai. Pelaksanaan penelitian bertempat di Laboratorium Mikrobiologi Fakultas Farmasi Universitas Muslim Indonesia.

\section{Alat dan Bahan}

Alat yang digunakan Bejana maserasi, Cawan Petri (Normax), Inkubator (Memmert), Autoklaf (Smic Model YX-280B), Oven (Memmert), Enkas, Laminar Air Flow (LAF), Spektrofotometri UV-Vis (Genesis), Timbangan Analitik (Chyo), timbangan kasar (O'Haus)

Bahan yang digunakan Biakan Mikroba Uji (Bacillus subtilis, Escherichia coli, Pseudomonas aeroginosa, Salmonella typhi, Staphylococcus aureus, Streptococcus mutans, Streptococcus epidermis dan Vibrio cholerae), Dimetil Sulfoksida (DMSO), Etanol 96\%, Medium Glukosa Nutrient Agar (GNA) (Merck), Larutan $\mathrm{NaCl}$ Fisiologis 0,9\%, dan Umbi Talas Ketan (Colocasia esculenta).

\section{Prosedur Penelitian}

\section{Ekstraksi sampel}

Sampel umbi talas ketan (Colocasia esculenta) di sortasi dan dibersihkan dengan menggunakan air yang mengalir, kemudian dikeringkan dengan cara diangin-anginkan dan tidak terkena sinar matahari langsung. 
Antibacterial Activity Assay Of Ethanolic Extract Of Bulbs Sticky Taro (Colocasia esculenta) Use TLC-Bioautografi

Sampel umbi talas ketan ditimbang sebanyak 318 gram kemudian dimasukkan ke dalam wadah maserasi, lalu ditambahkan etanol 96\% (hingga simplisia tersebut terendam) dan dibiarkan selama 5 hari dengan pengadukan sesering mungkin dalam bejana tertutup dan terlindung dari cahaya, kemudian disaring dan ampasnya direndam lagi dengan cairan penyari yang baru. Hal ini dilakukan hingga proses ekstraksi sempurna. Hasil penyarian yang didapat kemudian diuapkan dengan menggunakan rotavapor hingga diperoleh ekstrak etanol kental.

\section{Penyiapan Mikroba Uji}

Kultur murni bakteri, diambil dari biakan masing-masing satu ose kemudian diinokulasi pada medium GNA miring dan diinkubasi selama $1 \times 24$ jam pada suhu $37^{\circ} \mathrm{C}$. Mikroba uji hasil peremajaan, disuspensikan dengan larutan $\mathrm{NaCl}$ fisiologis $0,9 \%$ dan dimasukkan kedalam kuvet, kemudian diukur transmitannya menggunakan spektrofotometer dengan panjang gelombang $580 \mathrm{~nm}$ pada $25 \%$ untuk bakteri dan $75 \%$ untuk jamur. Sebagai blangko digunakan $\mathrm{NaCl}$ fisiologis $0,9 \%$ steril.

\section{Pengujian Skrining Antimikroba}

Ekstrak etanol talas ketan (Colocasia esculenta) ditimbang sebanyak $10 \mathrm{mg}$ lalu dilarutkan dengan DMSO sebanyak $200 \mu \mathrm{l}(0,2$ $\mathrm{ml}$ ). Setelah larut ditambahkan medium GNA 9,8 $\mathrm{ml}$ sehingga diperoleh konsentrasi $1 \mathrm{mg} / \mathrm{ml}$. Campuran tersebut dituang kedalam cawan petri lalu dihomogenkan dan dibiarkan memadat. Bakteri yang telah disuspensikan, masing-masing diambil $20 \mu \mathrm{l}$ menggunkan mikropipet dan digoreskan diatas medium yang telah memadat menggunakan ose bulat, kemudian diinkubasi pada suhu $37^{\circ} \mathrm{C}$ selama 1x24 jam. Hasil inkubasi diamati aktivitas antibakterinya yang ditandai dengan ada atau tidaknya pertumbuhan bakteri.

\section{Uji KLT Bioautografi}

Hasil kromatogram ekstrak etanol umbi talas ketandilakukan pengujian KLT-Bioautografi langsung dengan cara media GNA steril sebanyak $10 \mathrm{ml}$ dituang ke dalam cawan petri steril, lempeng KLT yang telah dielusi dengan eluen $\mathrm{n}$-heksan : etil asetat (4:1), diletakkan di atas permukaan medium agar yang telah disuspensi dengan bakteri uji dan dibiarkan selama 60 menit. Setelah itu lempeng tersebut diangkat dan dikeluarkan, selanjutnya media diinkubasi pada suhu $37^{\circ} \mathrm{C}$ selama 1×24 jam. 
Antibacterial Activity Assay Of Ethanolic Extract Of Bulbs Sticky Taro (Colocasia esculenta) Use TLC-Bioautografi

Pembuatan Pereaksi dan Identifikasi Komponen Kimia

Dilakukan identifikasi golongan komponen kimia yang aktif antimikroba meliputi pereaksi penampak bercak saponin, flavonoid, dan tanin(Sustrisno, 1993). Untuk penampak bercak beberapa golongan senyawa tertentu yaitu kromatogram disemprot dengan menggunakan pereaksi semprot sebagai berikut : Kromatogram disemprot dengan menggunakan pereaksi semprot untuk masing-masing komponen kimia berikut :

\section{Pereaksi Flavanoid}

\section{Aluminium klorida}

Dipanaskan kromatogram suhu $110^{\circ} \mathrm{C}$ selama 10 menit dan diamati noda yang berflourosensi pada lampu UV, noda yang berflourosensi kuning adalah senyawa golongan flavanoid. Setelah disemprot tampak bercak berpendar dalam sinar UV $366 \mathrm{~nm}$.

2. Tembaga sulfat sitrat (pereaksi Benedict)

Pereaksi ini mengurangi atau meniadakan pendaran dari senyawa dengan gugus odihidroksi (pendaran dalam sinar
UV 366); bila flavanoid tidak mempunyai gugus tersebut maka pendaran tidak berubah atau menjadi lebih intensif (dalam hal ini sering kali warna pendaran berubah).

\section{Timbal asetat}

Bercak berpendar dalam sinar UV $366 \mathrm{~nm}$.

\section{Pereaksi alkoloid}

\section{Dragendorff-Munier}

Setelah lempeng disemprot dipanaskan pada suhu $110^{\circ} \mathrm{C}$, tampak bercak berwarna coklat.

\section{Yodium-KI}

Setelah lempeng disemprot dikeringkan diudara, tampak bercak berwarna coklat.

\section{Dragendorff-HCL}

Setelah lempeng disemprot dikeringkan diudara, tampak bercak berwarna jingga sampai coklat.

\section{HASIL PENELITIAN}

\section{Hasil ekstraksi umbi talas ketan} (Colocasia esculenta)

Hasil ekstraksi umbi talas ketan (Colocasia esculenta) sebanyak 318 gram dengan metode maserasi menggunakan etanol $96 \%$ diperoleh 20 gram ekstrak etanol kental, terlihat pada tabel 1. 
Antibacterial Activity Assay Of Ethanolic Extract Of Bulbs Sticky Taro (Colocasia esculenta) Use TLC-Bioautografi

Tabel 1. Hasil ekstraksi umbi talas ketan (Colocasia esculenta).

\begin{tabular}{ccc}
\hline No. & Sampel & Bobot (gram) \\
\hline 1. & Umbi talas ketan & 318 \\
2. & Ekstrak etanol & 20 \\
\hline
\end{tabular}

\section{Pengujian skrining antimikroba}

Pengujian skrining antimikroba ekstrak etanol umbi talas ketan (Colocasia esculenta) terhadap bakteri uji Salmonella thypi, Shigella dysentriae, Staphylococcus aureus, epidermidis, Vibrio cholerae, Pseudomonas aeruginosa, Escherichia coli, dan Bacillus subtilis menunjukkan bahwa ekstrak etanol memberikan aktivitas antibakteri pada semua bakteri uji tersebut.

Streptococcus mutans, Streptococcus

Tabel 2. Hasil skrining antibakteri ekstrak etanol umbi talas ketan (Colocasia esculenta) terhadap beberapa bakteri uji

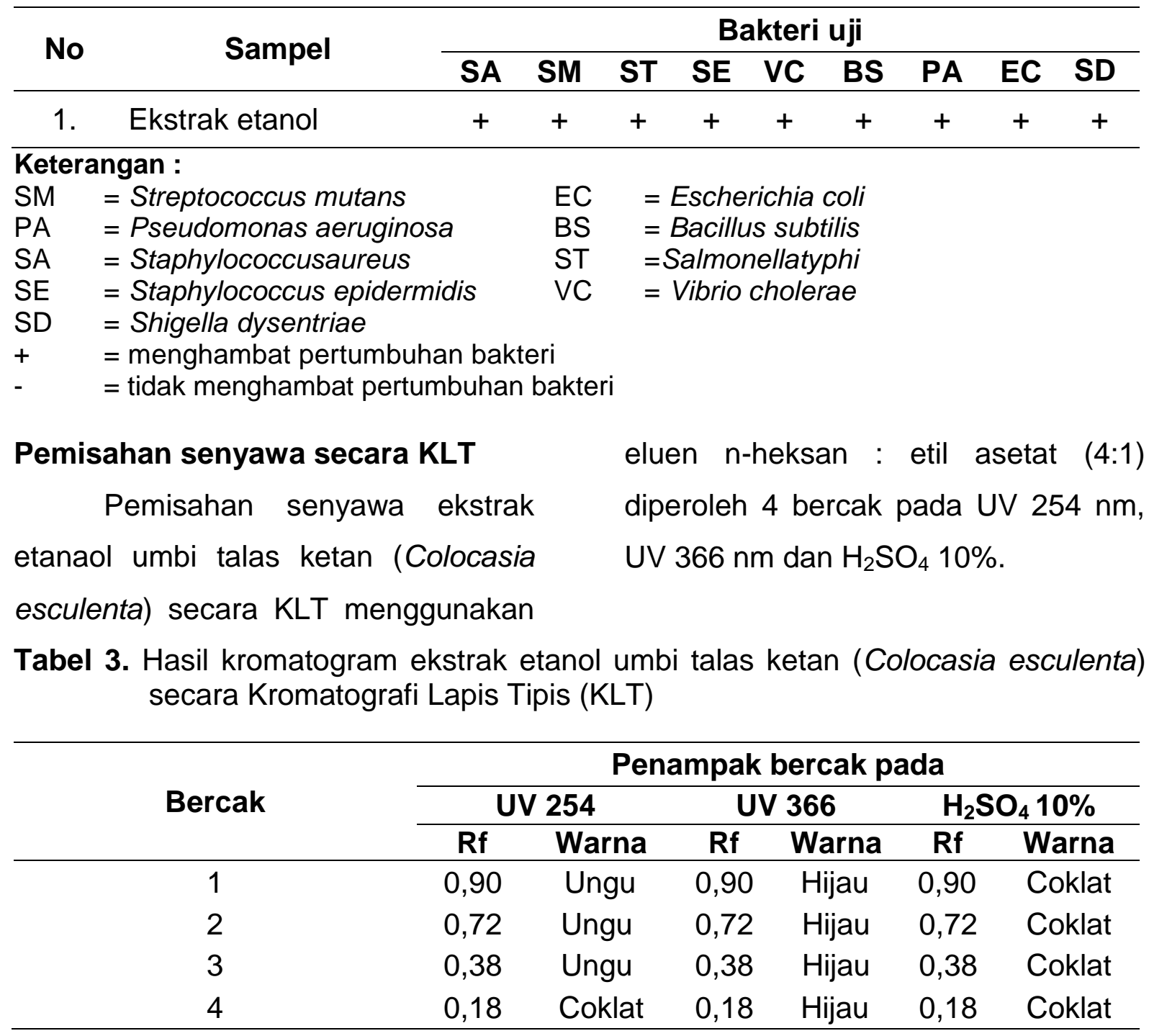


Antibacterial Activity Assay Of Ethanolic Extract Of Bulbs Sticky Taro (Colocasia esculenta) Use TLC-Bioautografi

Hasil pengujian secara KLT-

\section{Bioautografi}

Pada pengujian ekstrak etanol umbi talas ketan (Colocasia esculenta) secara KLT-Bioautografi diperoleh 4 bercak yang dapat menghambat pertumbuhan mikroba Salmonella thypi, Shigella dysentriae, Staphylococcus aureus, Streptococcus mutans, Streptococcus epidermidis, Vibrio cholerae, Pseudomonas aeruginosa, Escherichia coli, dan Bacillus subtilis. Hasilnya dapat dilihat pada tabel 4.

Tabel 4. Hasil pengujian aktivitas antibakteri dari ekstrak etanol umbi talas ketan (Colocasia esculenta) secara KLT-Bioautografi

\begin{tabular}{|c|c|c|}
\hline Bercal & Rf & Bakteri uji \\
\hline 1 & 0,90 & BS \\
\hline 2 & 0,72 & $\mathrm{PA}, \mathrm{VC}, \mathrm{SD}, \mathrm{SE}, \mathrm{SA}$ \\
\hline 3 & 0,38 & SD, PA, EC,ST,SE,VC,SA \\
\hline 4 & 0,18 & - \\
\hline \multicolumn{3}{|c|}{$\begin{array}{lll}\text { Keterangan : } & & \\
\text { SM = Streptococcus mutans } & \text { EC } & \text { Escherichia coli } \\
\text { PA = Pseudomonas aeruginosa } & \text { BS } & \text { Bacillus subtilis } \\
\text { ST = Salmonella typhi } & \text { SA } & \text { Staphylococcus aureus } \\
\text { SE = Staphylococcus epidermidis } & \text { VC } & \text { Vibrio cholerae } \\
\text { SD = Shigella dysentriae } & \end{array}$} \\
\hline
\end{tabular}

\section{Identifikasi komponen aktif}

Hasil identifikasi kompenen kimia aktif ekstrak etanol umbi talas ketan (Colocasia esculenta) dengan beberapa pereaksi penampak bercak yaitu aluminium klorida dan pereaksi dragendorf diperoleh bahwa komponen kimia pada noda yang dapat menghambat mikroba uji memberikan hasil positif terhadap penampak bercak golongan senyawa alkaloid dan flavanoid, terlihat pada tabel 5.

Tabel 5. Hasil identifikasi komponen kimia aktif ekstrak umbi talas ketan (Colocasia esculenta)

\begin{tabular}{ccccc}
\hline \multirow{2}{*}{ Bercak } & \multirow{2}{*}{$\mathbf{f}$} & \multicolumn{2}{c}{ Warna pada penampak bercak } & \multirow{2}{*}{ Keterangan } \\
\cline { 3 - 4 } & & $\mathrm{AlCl}_{3}$ & Dragendorff & \\
\hline 1 & 0,38 & - & Jingga & Alkoloid \\
\hline
\end{tabular}

\section{PEMBAHASAN}

Sumber daya alam yang memilpah di Indonesia memicu peningktan disektor penelitan sains yang sampai saat ini masih terus berlanjut. Sejak zaman nenek moyang dulu, telah digunakan tumbuhtumbuhan sebagai ramuan obat dan 
Antibacterial Activity Assay Of Ethanolic Extract Of Bulbs Sticky Taro (Colocasia esculenta) Use TLC-Bioautografi

sampai saat ini pula terus berkembang dengan adanya penelitian dan pengujian terhadap tumbuhan tertentu yang berkhasiat sebagai pengobatan, baik didalam maupun diluar negeri. Sampel yang digunakan pada penelitian ini yaitu umbi talas ketan (Colocasia esculenta). Dengan dasar pemilihan sampel yaitu pada masyarakat digunakan sebagai obat bisul dan luka bakar.

Umbi talas ketan (Colocasia esculenta) dikeringkan dan diekstraksi dengan metode maserasi menggunakan pelarut etanol 96\%. Pemilihan metode ini karena struktur sampel yang lunak dan menjaga agar senyawa kimia dalam sampel tidak rusak oleh pemanasan, selain itu metode ini mudah, praktis, dan ekonomis. Penggunaan etanol 96\% memiliki kandungan air yang sedikit sehingga menghindari rusaknya ekstrak dengan tumbuhnya jamur serta tidak memberikan efek toksik.

Hasil ekstraksi umbi talas ketan (Colocasia esculenta) sebanyak 318 gram dengan metode maserasi menggunakan etanol 96\% diperoleh 20 gram ekstrak etanol kental. Ekstrak uji dilarutkan dengan DMSO (Dimetil sulfoksida) sebanyak $20 \mu \mathrm{L}$, karena DMSO dapat melarutkan komponen kimia polar maupun non polar tanpa memberikan penghambatan terhadap beberapa bakteri uji serta ekstrak diharapkan terdispersi merata diseluruh medium untuk mendapatkaan hasil yang homogen.

Pengujian skrining aktivitas antibakteri menggunakan 9 bakteri antara lain Staphylococcus epidermidis, Shigella dysentriae, Streptococcus mutans, Staphylococcus aureus, Salmonella thypi, Vibrio cholerae, Pseudomonas aeuruginosa, Escherichia coli, Bacillus subtilis. Menurut Brooks (2001) pemilihan mikroba ini didasarkan pada sifat patogenik. Staphylococcus epidermidismerupakan penyebab infeksi alat kateter yang menyebabkan endokarditis serta infeksi kulit. Streptococcus mutansmerupakan bakteri anaerob Gram positif yang dapat menyebabkan karies pada gigi. Staphylococcus aureusmerupakan bakteri kokus Gram positif yang bersifat patogenik penyebab infeksi kulit dan makanan. Salmonella thypi dan Escherichia colimerupakan bakteri anaerob fakultatif, Gram negatif yang bersifat patogenik penyebab utama diare kronik, tifoid dan infeksi saluran kemih. Vibrio choleraemerupakan bakteri bentuk koma, aerob dan menghasilkan endotoksin, penyebab kolera.Bacillus subtilisbakteri batang 
Antibacterial Activity Assay Of Ethanolic Extract Of Bulbs Sticky Taro (Colocasia esculenta) Use TLC-Bioautografi

besar, Gram posiif, aerob yang tumbuh pada makanan dan menyebabkan keracunan pada makanan.

Pengujian skrining antibakteri dilakukan untuk mendapatkan ekstark aktif yang dapat menghambat bakteri uji. Metode yang digunakan adalah metode dilusi padat dengan konsentrasi $1 \mathrm{mg} / \mathrm{mL}$. penggunaan konsentrasi tersebut karena menurut Hoffman (1991) ekstrak dikatakan aktif jika pada konsentrasi $1 \mathrm{mg} / \mathrm{mL}$ menunjukan hambatan pertumbuhan bakteri dan jamur, maka ekstrak tersebut potensial untuk diteliti daya antibakterinya.

Pada hasil uji skrining aktivitas antibakteri menunjukan bahwa ekstrak etanol pada konsentrasi $1 \mathrm{mg} / \mathrm{mL}$ menghambat semua bakteri uji;Staphylococcus epidermidis, Shigella dysentriae, Streptococcus mutans, Staphylococcus aureus, Salmonella thypi, Vibrio cholerae, Pseudomonas aeuruginosa, Escherichia coli, Bacillus subtilis.

Pengujian selanjutnya analisis KLT-Bioautogtafi, metode ini merupakan pengujuan lanjutan bertujuan untuk mengetahui komponen kimia apa yang memberikan aktivitas antibakteri dari ekstrak etanol umbi talas ketan (Colocasia esculenta). Metode yang digunakan dalam KLT-
Bioautografi ialah metode kontak, dengan menempelkan lempeng KLT pada medium yang telah disuspensikan dengan bakteri uji selama 60 menit. Dasar pemilihan metode ini, agar memudahkan dalam pengamatan identifikasi komponen kimia aktif, relatif aman bagi peneliti dan juga dapat memperkecil kesalahan yang mungkin terjadi dalam penelitian. Prinsip kerja dari metode ini didasarkan atas difusi dari senyawa yang telah dipisahkan dengan kromatografi lapis tipis.

Hasil pengujian aktivitas antimikroba ekstrak etanol umbi talas ketan secara KLT-Bioautografi menggunakan eluen $n$-heksan : etil asetat (4:1) menunjukan bahwa bercak dengan nilai $\operatorname{Rf} 0,38$ menghambat bakteri Shigella dysentriae, Staphylococcus aureus, Staphylococcus epidermidis, Pseudomonas aeruginosa, Escherchia coli, Salmonella typhy dan Vibrio cholera. Berdasarkan hasil identifikasi golongan komponen kimia aktif ekstrak etanol umbi talas ketan (Colocasia esculenta) menunjukan bahwa nilai $\mathrm{Rf}$ 0,38 adalah golongan alkaloid dengan menggunakan pereaksi Dragendorff.

\section{KESIMPULAN}

Berdasarkan hasil yang diperoleh dari penelitian yang telah 
Antibacterial Activity Assay Of Ethanolic Extract Of Bulbs Sticky Taro (Colocasia esculenta) Use TLC-Bioautografi

dilakukan maka dapat disimpulkan bahwa :

Ekstrak etanol umbi talas ketan (Colocasiaesculenta) memberikan aktivitas terhadap bakteri Staphylococcus epidermidis, Shigella dysentriae, Staphylococcus aureus, Salmonella thypi, Vibrio cholerae, Pseudomonas aeuruginosa, Escherichia coli. Golongan komponen kimia aktif yang memberikan aktivitas antibakteri secara KLT-Bioautografi adalah golongan alkaloid menggunakan pereaksi Dragendorff pada nilai dengan nilai $\operatorname{Rf} 0.38$.'

\section{DAFTAR PUSTAKA}

Adnan,

M., 1997. Teknik Kromatografi,Penerbit Andi, Yogyakarta.

Dalimatra, S., 2006. Atlas Tumbuhan Obat IndonesiaJilid 4. Puspa Swara, Jakarta.

Difco, 1988. Cultur Media Handbook, E., Merck, Darmstadt, Federal Republik of Germany

Djide, N., Sartini, Kadir, S., 2005. Mikrobiologi Farmasi Dasar, Universitas Hasanuddin: Makassar.

Djide, N., Sartini, Kadir, S., 2005. Analisis Mikrobiologi Farmasi, Laboratorium Mikrobiologi Farmasi dan Bioteknologi Farmasi, Jurusan Farmasi Fakultas MIPA, Universitas Hasanudin, Makassar.
Eddy, N., Nabuk O., 2009. Inhibitive and Adsorption Properties of Ethanol Extract of Colocasia esculenta Leaves for The Corrosion of Mild Steel in $\mathrm{H}_{2} \mathrm{SO}_{4}$. Int. J. Phys. Sci., Vol. 4 (4), pp. 165-171.

Holt., John, G. 2000. Bergey's Manual of Determinative Bacteriology $10^{\text {th }}$ Edition. The Williams \& Wilkins Company, Baltimore, Maryland21202, United State of America.

Jawetz Melinick \& Adelberg., 1995. Mikrobiologi Kedokteran, Edisi 20., Kedokteran EGC, Jakarta.

Kaltzung., dan Bertram. 2004. Farmakologi Dasar dan Klinik. Terjemahan bagian Farmakologi Fakultas Kedokteran Universitas Airlangga. Salemba Medika: Surabaya.

Kusumo,S Hasanah,M., Moeljopawiro,S., Thohari,M., Subandriyo., Hardja,M., Nurhadi,A., dan Kasim,H. 2002. Panduan Karakterisasi dan Evaluasi Plasma Nutfah Talas.Bogor : Departemen Pertanian Badan Penelitian dan Pengembangan Pertanian Komisi Nasional Plasma Nutfah.

Sastroamidjoyo, H., 1989, Kromatografi, Edisi II, Liberti, Yogyakarta.Setiabudy., R., Vincent. 1995. Pengantar Antimikroba dalam Farmakologi dan Terapi. Edisi 4. Badan Farmakologi Fakultas Kedokteran Universitas Indonesia: Jakarta. 